facturing establishments employed about 72 per cent of the total, and three groups-electrical equipment and supplies, transport equipment, and chemical and allied products-employed 55 per cent of all scientists and engineers in manufacturing establishments. Most of the scientists and engineers in the electrical equipment industries group were in industries primarily concerned with electronics. Those in the transport equipment industry were in establishments classified in the aircraft and parts industry, and nearly half the engineers and scientists in the chemical industries were in works producing basic industrial chemieals. Of about 225,000 scientists and engineers in non-manufacturing industries, nearly twofifths, mostly engineers, wero in the construction industry and closely related engineering and architectural services industry. About 37 per cent were primarily engaged in performing or administering research and development. The number of technicians increased by about 5 per cent in the period, about 573,000 being employed in January 1961 .

\section{Trade Unions and the Law}

A BRoAdsheet by J. Cotton, entitled Trade Unions and the Law, concludes the examination by Political and Economic Planning of Trade Unions in a changing society (Planning, 30, No. 479; March 23, 1964. Pp. 119-150. London: Political and Economic Planning. 4s.). It discusses the position at law of five aspects of trade unionism in which either the rights of the individual are affected or the public interest is involved. These are: (a) admission to, and expulsion from, a Trado Union; (b) elections to Trade Union offices; (c) the effect of collective agreement; (d) strikos. In general, there appears to be no need for sweeping ehanges in the law, and mostly the Trade Unions themselves could take action where extended legal control has been suggosted. If closed-shop agreements increase markedly, some form of protection may be needed for the individual who is refused admission. In connexion with Union elections. the Trades Union Congress could bo empowered by member Unions to enquire into elections alleged to have been misconducted or the Chief Registrar of Friendly Societies could be given the power of supervision and investigation when noedod. Legislation to prevent unofficial strikes is unlikely to be effective unless socioty is prepared to surrender some principles regarded as essential in a democracy.

\section{The Parliament of the European Communities}

A Broadsheet by M. Forsyth, entitled The Parliament of the European Communities, forms part of a major investigation by Political and Economic Planning of Britain and the European Common Market (Planning, 30, No. 478; March 1964. Pp. 120. London: Political and Economic Planning. 10s.6d.). It has been published after discussions by the Steoring Group responsible for the project. It reviews first the development of international parliamentary assemblies and then discusses, in two successive chapters, the structure and organization of the European Parliament, and its powers and functions. The fourth and final chapter discusses the future of the European Parliament. It includes the immediate problems of strengthening its authority, the possibility of direct elections and ultimately of increasing its power. The English text of the Rules of Procedure of the European Parliament is appended.

\section{Rubber and Plastics Research at Shawbury}

THE forty-fourth annual report and accounts of the Rubber and Plastics Research Association of Great Britain covers the year ending December 1963 (Pp. 42. Shawbury, Shrewsbury: Rubber and Plastics Research Association of Great Britain, 1964). It contains a full list of staff and officers of the Association, a list of member firms, a list of publications, a résumé of the activities of the Association, and the annual bulance sheet and accounts. During the year, the Government grant for the quinquennium 1964-68 was agreed with the Department of Scientific and Industrial Research. The terms of the grant show a small but encouraging increase in Government support which appears also to be reflected in the reaction of industry to the new subscriptions for certain member firms. The year saw tho completion of as substantial programme of building and the Association looks forward to a period of expanding activities, particularly in the field of plastics. A notable feature in engineering to-day is the incursion of polymers (plastics and rubbers) into more and more fields. In keeping with these developments, the Association has initiated a programme of work aimed at helping to produce rational design procedures for plastics with particular emphasis on the elucidation of eritical failure criteria. Tho 'Shawbury Damper', a potential replacement for hydraulic damping units in vehicles, etc., which employs rubber as the working substance, has aroused wide industrial interest, and licences have been granted to several companies to go ahoad with development for production. Process research and development have continued on many lines, including calendering, blank cutting, fluid bed vulcanization, moulding machinery and materials evaluation. More fundamental work has included investigation of flow of polymer melts, the role of the fibre/resin interface in determining the strength of reinforeed plasties. and the decomposition of polymers during processing.

\section{Wool Research in Australia}

THE annual report for 1962-63 of the C.S.l.K.O. Wool Research Laboratories comments on the expansion of the three Laboratories during 1959-63 as the result of considerably increased support from C.S.I.R.O. and the wool growers (Pp. 49. Melbourne: Commonwealth Scientific: and Industrial Research Organization, 1963). The report surveys growing and well co-ordinated laboratories that provide a stimulating and progressive outlook for wool rescarch. The Division of Protein Chemistry at Melbourne uses all modern techniquos to study wool and allied proteins; the summarized results are impressive. Outside the field of protein structure the laboratory has improved sheep shearing, developed an aeration method for fell-mongering sheep-skin pieces, provided sheop-skins as a nursing aid and shown that wool fibres do not earry bacteria in hospital wards. An intriguing development is the comprossion of wool into bales by packing tho fleece into a polythene bag which is evacuated with a milking machine pump. Tho Division of Textile Physics at Sydney deals with a number of unique properties of wool, such as permanent set and the effect of moisture absorption on the properties and behaviour of wool and wool products. The revorsible extension and contraction of wool cloth on absorption and desorption of moisturo provide some particularly interesting results. The Division of Textile Industry at Geelong has provided many industrial requirements from branding fluids for sheep to 'Easy-Care' garments. The removal of burr and seed without carding has boen achieved and further progress is reported on jet scouring. Almost a hundrod published papers arn listed from the three Laboratories during 1962-63.

\section{The East African Wildlife Journal}

The East African Wildlife Journal is a new publication -ponsored by the East African Wild Life Society (P.O. Box 20110, Nairobi, Kenya), a Socioty formed by the union of the formor three wild-life societios of Kenya, Uganda and Tanganyika (1, August 1963. Pp. 131. Nairobi; East African Wild Life Society, 1963. Annual subscription 17s. 6d.; 2.50 dollars). It is intended for the publication of papers on all aspects of research doaling with wild life, not necessarily only those concerning East Africa. This first volume contains papers on birds of prey, animal husbandry and wild life, elephants, 